\title{
Toxoplasma gondii: Are There any Implications for Routine Blood
}

\section{Screening?}

\author{
Masoud Foroutan, ${ }^{1, *}$ and Hamidreza Majidiani ${ }^{1, * *}$ \\ ${ }^{1}$ Department of Parasitology, Faculty of Medical Sciences, Tarbiat Modares University, Tehran, IR Iran \\ "Corresponding author: Masoud Foroutan, Department of Parasitology, Faculty of Medical Sciences, Tarbiat Modares University, Tehran, IR Iran. E-mail: \\ m.foroutan@modares.ac.ir \\ ${ }^{* *}$ Corresponding author: Hamidreza Majidiani, Department of Parasitology, Faculty of Medical Sciences, Tarbiat Modares University, Tehran, IR Iran. E-mail: \\ h.majidiani@modares.ac.ir
}

Received 2017 January 24; Revised 2017 January 30; Accepted 2017 January 30.

Keywords: Blood Donors, Seroprevalence, Toxoplasma gondii

\section{Dear Editor,}

Toxoplasma gondii is an obligate intracellular member of phylum Apicomplexa, which is the most prevalent parasitic infection in humans and many warm blooded animal species, involving one-third of the world population, specifically in developing countries with the prevalence rate varying between $30 \%$ and $60 \%$ (1-3). Toxoplasma gondii is considered as a transfusion-transmissible infection. In addition to blood-borne transmission, Toxoplasma could enter an intermediate host by food-borne (consuming raw meat), and zoonotic (ingesting oocysts shed by infected cats), congenital (mother to fetus) routes as well as organ transplantation (1, 3-5). Risk of transmission of toxoplasmosis by blood transfusion from seemingly asymptomatic and healthy individuals, who are carriers of infection, places an extra burden on the global population, especially where toxoplasmosis is more common. Seropositive individuals, particularly those at the acute stage of infection may possess a remarkable role in transmission $(5,6)$. Some reports have documented the transmission of parasites by transfusion of blood and leukocytes or the viability of parasites in citrated blood at $5^{\circ} \mathrm{C}$ for more than 50 days $(7,8)$. Reportedly, delay and prevention of disease transmission could not be accomplished by refrigeration of blood packs during storage periods (7). Blood products are often donated to patients with sickle cell anemia, aplastic anemia, thalassemia, cancer chemotherapy, and to those who are treated with immunosuppressive agents, such as transplantation recipients. Since pre-transfusion screening for $T$. gondii has not yet been considered, vulnerable clinical groups, such as immunocompromised patients, were at high risk for acute and severe toxoplasmosis by donated blood $(5,9,10)$.
In order to evaluate the molecular epidemiology of T. gondii in blood donors, the researchers systematically searched 6 databases (Science Direct, Web of Science, Scopus, PubMed, Google Scholar and, Ovid), using related keywords. Only those papers that estimated the toxoplasmosis status using both serologic and molecular methods were selected. Data extraction was performed on the basis of title, first author, country, study population, number of positive subjects in terms of IgG, IgM or both, used methods (molecular and serologic techniques), and references.

Finally, 6 papers met the criteria to be included in this paper $(6,9-13)$ (Table 1$)$. In a recent systematic review and meta-analysis, seroprevalence of T. gondii in blood donors was reported as 33\% (95\% CI, $28 \%$ to 39\%) from a global perspective (5). According to some documentations with regards to $T$. gondii viability in blood products for several weeks, the risk of transmission of this infectious agent will be increased by blood transfusion. For instance, in the study of Siegel et al. transmission of Toxoplasma through leukocytes transfusion from infected donors was documented (7). The same route of infection was implied by Roth et al. (8). Also a unique case of acquired retinochoroiditis resulted from toxoplasmosis was reported with platelet transfusion (14).

In the current study, regarding included articles based on molecular methods in blood donors, in the low proportion of IgM+ samples, DNA of the parasite was identified (Table 1). However, it is surprising that 2 papers reported higher acute toxoplasmosis using molecular methods in comparison to serology tests (IgM+ or both IgG + $/ \operatorname{IgM}+)(9,12)$. It seems that in blood samples that were diagnosed as either negative or positive only for IgG antibody (as an indicator for chronic infection), DNA of para- 
Table 1. Baseline Characteristics of Included Studies

\begin{tabular}{|c|c|c|c|c|c|c|c|c|c|c|}
\hline \multirow[t]{2}{*}{ Country } & \multirow[t]{2}{*}{ Study Population (n) } & \multicolumn{5}{|c|}{ Seroprevalence (n) } & \multicolumn{3}{|c|}{ Molecular Prevalence } & \multirow[t]{2}{*}{ Ref } \\
\hline & & IgG & IgM & Both IgG/IgM & Total Prevalence, No. (\%) & Serology Technique & Sample Size, $\mathbf{n}$ & Positive, $\mathbf{n}$ & Technique/Primr & \\
\hline \multirow[t]{4}{*}{ Taiwan } & 1783 & 161 & 0 & 5 & $166(9.3)$ & EIA & 1783 & 0 & Real-Time PCR & (6) \\
\hline & & & & & & & On all samples & & $\begin{array}{l}529 \text { bp Repeat Element (RE) } \\
\text { gene }\end{array}$ & \\
\hline & & & & & & & & & $\begin{array}{c}\text { 5'-CACAGAAGGGACAGAAGT- } \\
3^{\prime}\end{array}$ & \\
\hline & & & & & & & & & 5'-ТGGCCTTCATCTACAGTC-3' & \\
\hline \multirow[t]{6}{*}{ Iran } & 1480 & 182 & 81 & 23 & $286(19.3$ & EIA & 104 & 2 & Nested PCR & (13) \\
\hline & & & & & ) & & $\begin{array}{l}\text { On only IgM+ samles and on } \\
\text { both IgG+/IgM+ samples }\end{array}$ & & B1 gene & \\
\hline & & & & & & & & & $\begin{array}{l}\text { Outer primer: ( } 5^{\circ} \text {-CCG } \\
\text { TTGGTT CCG CCT CCT TC-3 })\end{array}$ & \\
\hline & & & & & & & & & 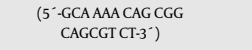 & \\
\hline & & & & & & & & & $\begin{array}{l}\text { Inner primer: ( } 5^{\circ} \text {-CCG CCT } \\
\text { CCT TCG TCCGTC GT-3-3') }\end{array}$ & \\
\hline & & & & & & & & & $\begin{array}{c}\text { (5 -GTG GGG GCG GAC CTC } \\
\text { TCT TG-3-3) }\end{array}$ & \\
\hline \multirow[t]{4}{*}{ Iran } & 235 & 80 & 4 & 0 & $84(35.7)$ & ELISA & 200 & 14 & Real-Time PCR & (12) \\
\hline & & & & & & & On selected samples & & SAG1 gene & \\
\hline & & & & & & & & & $\begin{array}{l}\text { SAGIF: } 5^{\prime-} \\
\text { GCTGTAACATTGAGCTCCTTGATTCCT } \\
3^{\prime}\end{array}$ & TG- \\
\hline & & & & & & & & & $\begin{array}{l}\text { SAGIR: 5'- } \\
\text { CCGGAACAGTACTGATTGTTGTCT } \\
\text { GAG--3' }\end{array}$ & \\
\hline \multirow[t]{4}{*}{ Iran } & 500 & 144 & 11 & 5 & $160(32)$ & ELISA & 11 & 1 & Real-Time PCR & (11) \\
\hline & & & & & & & On only IgM+ samles & & B1 gene & \\
\hline & & & & & & & & & $\begin{array}{l}\text { F: } 5^{\circ} \\
\text { GGAGGACTGGCACCTGGTGTCG- } \\
3^{-}\end{array}$ & \\
\hline & & & & & & & & & $\begin{array}{l}\text { R: } 5^{\circ} \text { - } \\
\text { TTGTTTCACCCGGACCGTTTAGCA } \\
3^{\circ}\end{array}$ & \\
\hline \multirow[t]{4}{*}{ Egypt } & 300 & 93 & 2 & 8 & 103 & ELISA & 300 & 18 & Real-time quantitative PCR & (9) \\
\hline & & & & & (34.3) & & On all samples & & B1 gene & \\
\hline & & & & & & & & & 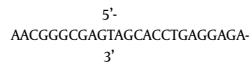 & \\
\hline & & & & & & & & & $\begin{array}{l}\text { 5'. } \\
\text { TGGGTCTACGTCGATGGCATGACA } \\
3^{\prime}\end{array}$ & \\
\hline \multirow[t]{5}{*}{ Egypt } & 150 & 98 & - & - & $98(65.3)$ & ELSA & 150 & 15 & Real-Time PCR & (10) \\
\hline & & & & & & & On all samples & & B1 gene & \\
\hline & & & & & & & & & $\begin{array}{c}\text { (TOXO-F): }\left(5^{\prime} \text {. }\right. \\
\text { TCCCCTCTGCTGGCGAAAGT- } \\
\left.3^{\prime}\right)\end{array}$ & \\
\hline & & & & & & & & & $\begin{array}{l}\text { (TOXO-R): }\left(5^{\prime} \text { - }\right. \\
\text { AGCGTTCGTGGTCAACTATCGATT } \\
\left.3^{\prime}\right)\end{array}$ & \\
\hline & & & & & & & & & $\begin{array}{l}\text { Taqman probe (6FAM- } \\
\text { TCTGTGCAACTTTGGTGTATTCGCAG- } \\
\text { TAMRA) to amplify the } 98 \text { bp } \\
\text { segment of the } 35 \text {-repititive } \\
\text { B1 gene }\end{array}$ & \\
\hline
\end{tabular}

Abbreviations: bp, base pair; EIA, enzyme immunoassay; ELISA, enzyme-linked immunosorbent assay; F, forward; PCR, polymerase chain reaction; R, reverse.

site may be identified. It should be noted that if a donor is seropositive for $T$. gondii, it does not necessarily mean that their blood will be infectious. Patients, who receive seropositive blood and later manifest toxoplasmosis, may not have been infected by transfusion and may have been previously infected, and symptoms of toxoplasmosis be- came evident due to their immunocompromised condition, or due to current infection by a blood-independent (for example transplanted tissue etc.) mechanism. In addition, screening donated bloods that merely relied on the presence of anti-T. gondii antibodies would likely neglect a high percentage of donors from an endemic country's 
donor pool, whereas only a very small fraction of donors were likely infectious. If testing turns out to be a viable strategy for endemic countries, it is likely that a test for the direct presence of the organism in blood (an antigen test or a DNA-based test) will be required. The literature on transfusion transmission toxoplasmosis is limited. The American association of blood banks (AABB) categorizes blood transmission of toxoplasmosis as rare: only 4 cases have been definitively demonstrated and those were associated with transfusion of granulocyte concentrates, as well as one possible case involving a platelet transfusion (www.aabb.org/tm/eid/Documents/227s.pdf) (5).

Though a relatively high seroprevalence was obtained in included studies, this finding is not necessarily representative of active infection. Given the differences in the number of IgM positive cases and the number of detected DNA of parasite by molecular methods in a few studies (represented in Table 1), it is suggested for future studies to use the Enzyme Linked Immunosorbent Assay (ELISA) as a standard serology method and then the polymerase chain reaction (PCR) as a canonical molecular procedure to reach more accurate and appreciable outcomes. In conclusion, this report illustrates that high serologic prevalence does not justify widespread donor screening, for 2 reasons 1) serology does not imply infectivity, and 2) a high serologic background prevalence (if used to eliminate donors) would result in major limitation on blood availability, thus, causing more harm than toxoplasmosis. It seems that a test for the direct presence of the organism in blood (an antigen test or a DNA based test) will be useful. The researchers of the current study suggest a future focus on this issue throughout the globe, especially parts of the world, which lack data on this subject.

\section{Acknowledgments}

The authors would like to thank all staff of the Department of Parasitology of Tarbiat Modares University, Tehran, Iran.

\section{Footnotes}

Authors' Contribution: The authors contributed equally to this manuscript.

Conflicts of Interest: The authors declared no potential conflicts of interest with respect to the research, authorship, and/or publication of this article.

Funding/Support: The authors received no financial support for the research, authorship, and/or publication of this article.
Ethical Aspects: Not required.

\section{References}

1. Foroutan-Rad M, Khademvatan S, Majidiani H, Aryamand S, Rahim F, Malehi AS. Seroprevalence of Toxoplasma gondii in the Iranian pregnant women: A systematic review and meta-analysis. Acta Trop. 2016;158:160-9. doi: 10.1016/j.actatropica.2016.03.003. [PubMed: 26952970].

2. Majidiani H, Dalvand S, Daryani A, Galvan-Ramirez ML, Foroutan-Rad M. Is chronic toxoplasmosis a risk factor for diabetes mellitus? A systematic review and meta-analysis of case-control studies. Braz J Infect Dis. 2016;20(6):605-9. doi: 10.1016/j.bjid.2016.09.002. [PubMed: 27768900].

3. Dubey JP. The history of Toxoplasma gondii-the first 100 years. J Eukaryot Microbiol. 2008;55(6):467-75. doi: 10.1111/j.15507408.2008.00345.x. [PubMed: 19120791].

4. Saki J, Shafieenia S, Foroutan-Rad M. Seroprevalence of toxoplasmosis in diabetic pregnant women in southwestern of Iran. J Parasit Dis. 2016;40(4):1586-9. doi: 10.1007/s12639-015-0735-4. [PubMed: 27876989].

5. Foroutan-Rad M, Majidiani H, Dalvand S, Daryani A, Kooti W, Saki J, et al. Toxoplasmosis in Blood Donors: A Systematic Review and Meta-Analysis. Transfus Med Rev. 2016;30(3):116-22. doi: 10.1016/j.tmrv.2016.03.002. [PubMed: 27145927].

6. Chiang TY, Hsieh HH, Kuo MC, Chiu KT, Lin WC, Fan CK, et al. Seroepidemiology of Toxoplasma gondii Infection among healthy blood donors in Taiwan. PLoS One. 2012;7(10). e48139. doi: 10.1371/journal.pone.0048139. [PubMed: 23133557].

7. Siegel SE, Lunde MN, Gelderman AH, Halterman RH, Brown JA, Levine AS, et al. Transmission of toxoplasmosis by leukocyte transfusion. Blood.1971;37(4):388-94. [PubMed: 4927414].

8. Roth JA, Siegel SE, Levine AS, Berard CW. Fatal recurrent toxoplasmosis in a patient initially infected via a leukocyte transfusion. Am J Clin Pathol.1971;56(5):601-5. [PubMed: 5287645].

9. El-Sayed NM, Abdel-Wahab MM, Kishik SM, Alhusseini NF. Do we need to screen Egyptian voluntary blood donors for toxoplasmosis?. Asian Pac J Trop Dis. 2016;6(4):260-4. doi:10.1016/s2222-1808(15)61027-1.

10. El-Geddawi O, El-Sayad M, Sadek N, Hussien N, Ahmed M. Detection of T. gondii infection in blood donors in Alexandria, Egypt, using serological and molecular strategies. Parasitologists United J. 2016;9(1):24. doi: 10.4103/1687-7942.192992.

11. Mahmoudvand H, Saedi Dezaki E, Soleimani S, Baneshi MR, Kheirandish F, Ezatpour B, et al. Seroprevalence and risk factors of Toxoplasma gondii infection among healthy blood donors in southeast of Iran. Parasite Immunol. 2015;37(7):362-7. doi: 10.1111/pim.12198. [PubMed: 25891186].

12. Zainodini N, Zare-Bidaki M, Abdollahi SH, Afrooz M, Ziaali N, Ebrahimian M, et al. Molecular and serological detection of acute and latent toxoplasmosis using real-time PCR and ELISA techniques in blood donors of rafsanjan city, iran, 2013. Iran J Parasitol. 2014;9(3):336-41. [PubMed: 25678917].

13. Sarkari B, Shafiei R, Zare M, Sohrabpour S, Kasraian L. Seroprevalence and molecular diagnosis of Toxoplasma gondii infection among blood donors in southern Iran. J Infect Dev Ctries. 2014;8(4):543-7. doi: 10.3855/jidc.3831. [PubMed: 24727522].

14. Nelson JC, Kauffmann DJ, Ciavarella D, Senisi WJ. Acquired toxoplasmic retinochoroiditis after platelet transfusions. Ann Ophthalmol. 1989;21(7):253-4. [PubMed: 2774432]. 